Prepared in cooperation with the

City of Lansing, Michigan, and U.S. Army Corps of Engineers

\title{
Flood-Inundation Maps for Grand River, Red Cedar River, and Sycamore Creek near Lansing, Michigan
}

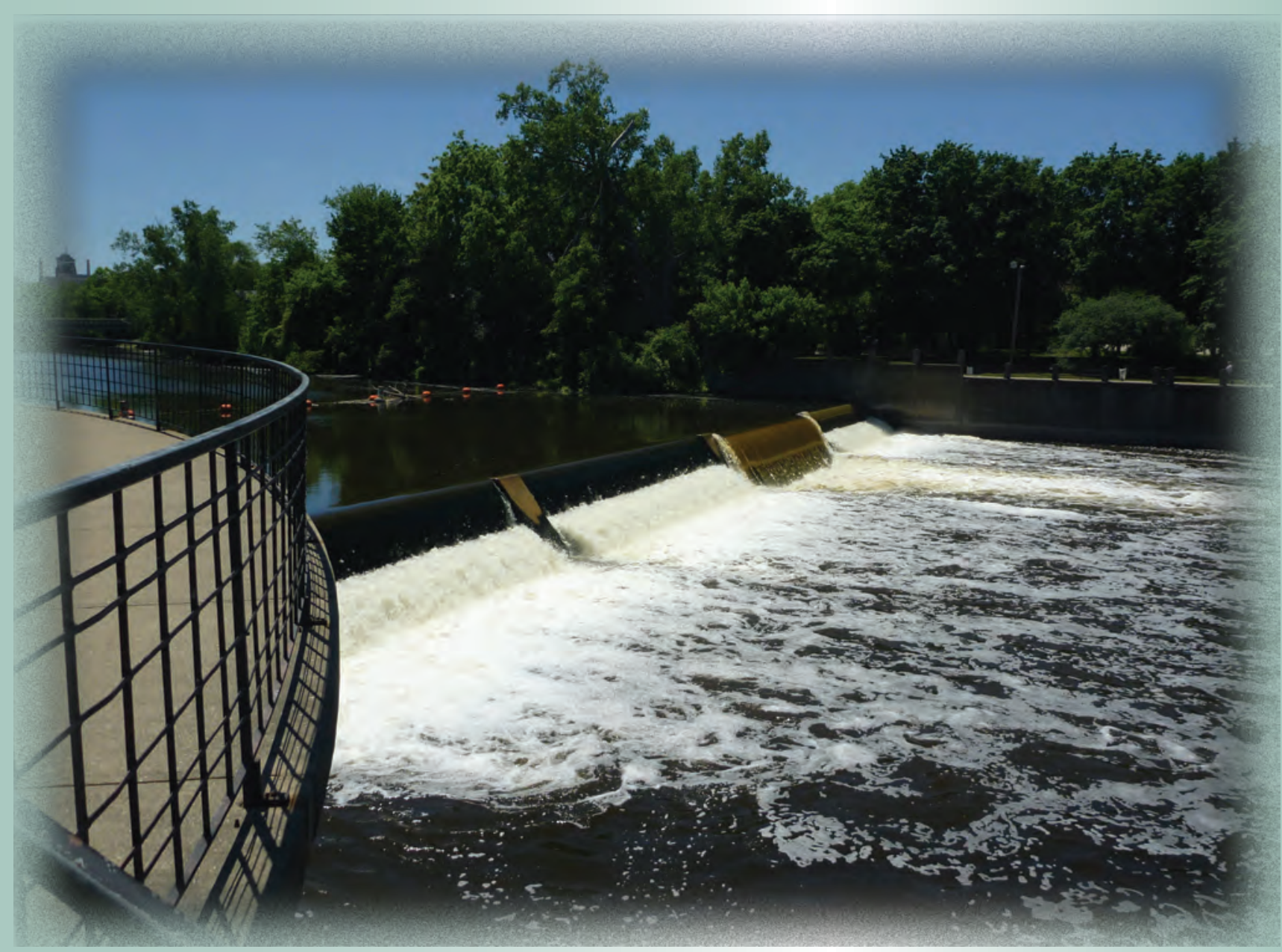

Scientific Investigations Report 2015-5101

Version 1.1 February 2016

U.S. Department of the Interior

U.S. Geological Survey 
Cover: View looking west across Grand River near the North Lansing Dam at Lansing, Michigan. (Photo by U.S. Geological Survey, June 2013) 


\section{Flood-Inundation Maps for Grand River, Red Cedar River, and Sycamore Creek near Lansing, Michigan}

By Matthew T. Whitehead and Chad J. Ostheimer

Prepared in cooperation with the

City of Lansing, Michigan, and U.S. Army Corps of Engineers

Scientific Investigations Report 2015-5101

Version1.1, February 2016 


\title{
U.S. Department of the Interior SALLY JEWELL, Secretary
}

\section{U.S. Geological Survey Suzette M. Kimball, Director}

\author{
U.S. Geological Survey, Reston, Virginia \\ First release: 2015 \\ Revised: January 2016 (ver. 1.1)
}

For more information on the USGS —-the Federal source for science about the Earth, its natural and living resources, natural hazards, and the environment—visit http://www.usgs.gov or call 1-888-ASK-USGS.

For an overview of USGS information products, including maps, imagery, and publications, visit http://www.usgs.gov/pubprod/.

Any use of trade, firm, or product names is for descriptive purposes only and does not imply endorsement by the U.S. Government.

Although this information product, for the most part, is in the public domain, it also may contain copyrighted materials as noted in the text. Permission to reproduce copyrighted items must be secured from the copyright owner.

Suggested citation:

Whitehead, M.T., and Ostheimer, C.J., 2015, Flood-inundation maps for Grand River, Red Cedar River, and Sycamore Creek near Lansing, Michigan (ver 1.1, February 2016): U.S. Geological Survey Scientific Investigations Report 2015-5101, 23 p., http://dx.doi.org/10.3133/sir20155101.

ISSN 2328-0328 (online) 


\section{Acknowledgments}

The authors thank the many local, state, and Federal agencies that have cooperated in the funding for the operation and maintenance of the streamgages throughout the country. We especially thank the City of Lansing, the Michigan Department of Transportation, and Michigan State University for their support of the three gages referred to in this report. 


\section{Contents}

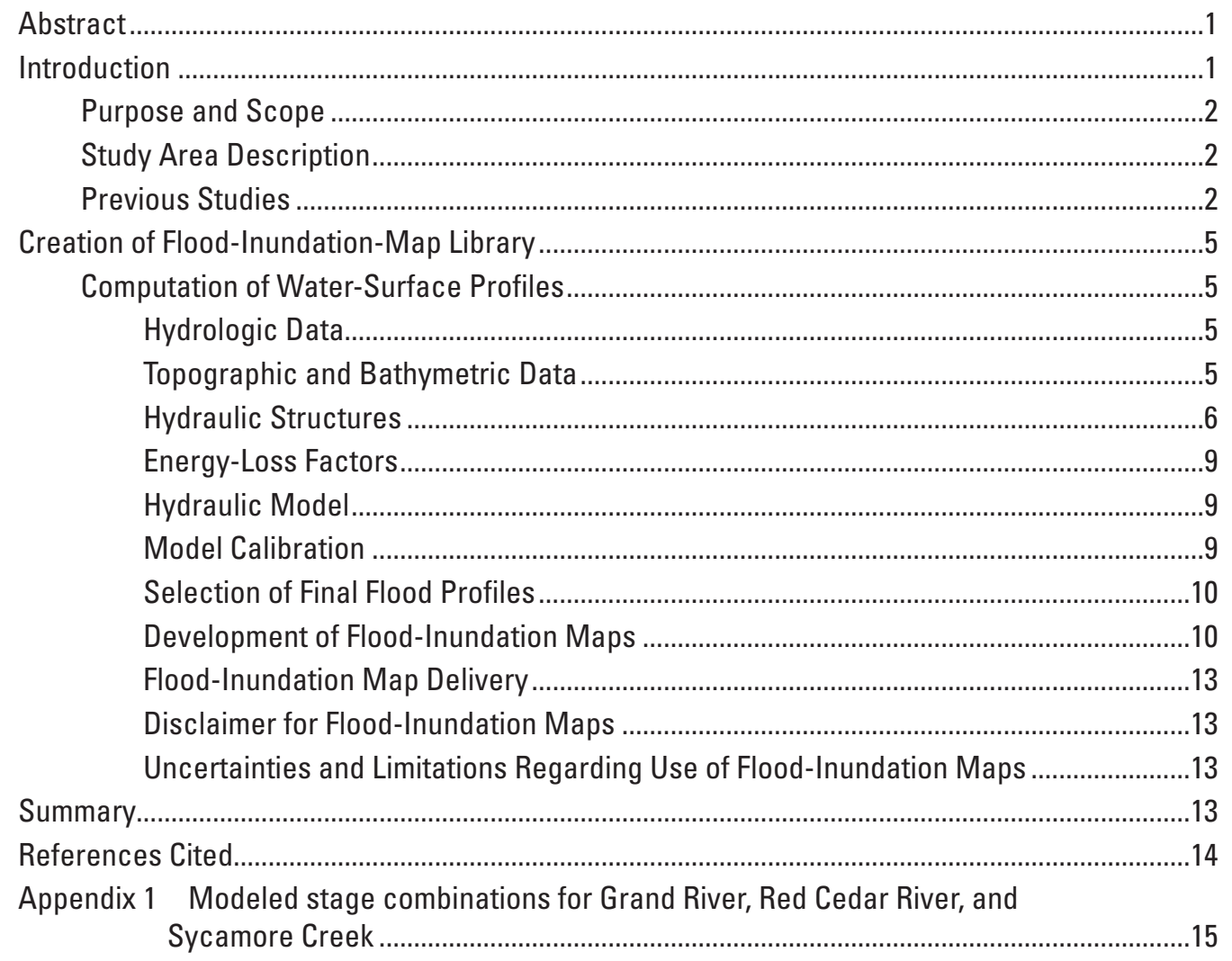

\section{Figures}

1. Map showing locations of selected streamgages and rivers and creeks.......................3

2. Map showing locations of increased flows due to increased drainage area ..................7

3. Map showing locations of selected USGS streamgages and stage sensors near

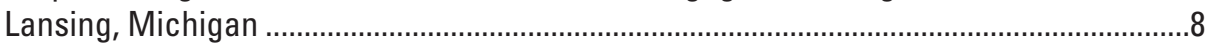

4. Graph showing percentages of tributary flows to main stem flows for selected streams near Lansing , Michigan ...................................................................................11

5. Diagram showing a modeled and approximated water-surface profile for Red Cedar River 


\section{Tables}

1. Description of study reaches.........................................................................................

2. U.S. Geological Survey streamgage information for the Grand River, the Red Cedar River, and Sycamore Creek near Lansing, Michigan...

3. Minimum and maximum target water-surface stages and National Weather Service designated stages for Grand River, Red Cedar River, and Sycamore Creek .......4

4. Selected stages and associated streamflows for respective stage-discharge relations for the Grand River, Red Cedar River, and Sycamore Creek streamgages referred to in this report......

5. Drainage areas at selected locations for the Red Cedar River and Sycamore

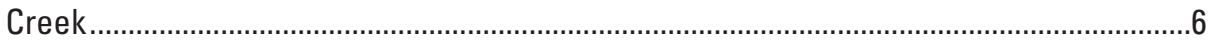

6. Range in Manning's roughness factors for selected streams ...........................................9

7. Calibration of model to target water-surface elevations at selected U.S. Geological Survey streamgages...........................................................................

8. Calibration of model to water-surface elevations at selected locations along selected streams for the flood of May 16, 2014

\section{Conversion Factors}

Inch/Pound to SI

\begin{tabular}{lcl}
\hline \multicolumn{1}{c}{ Multiply } & By & \multicolumn{1}{c}{ To obtain } \\
\hline foot $(\mathrm{ft})$ & Length & \\
mile (mi) & 0.3048 & meter $(\mathrm{m})$ \\
\hline & 1.609 & kilometer $(\mathrm{km})$ \\
\hline square mile $\left(\mathrm{mi}^{2}\right)$ & Area & \\
\hline & 2.590 & square kilometer $\left(\mathrm{km}^{2}\right)$ \\
\hline cubic foot per second $\left(\mathrm{ft}^{3} / \mathrm{s}\right)$ & Flow rate & \\
\hline
\end{tabular}

Vertical coordinate information is referenced to (1) stage, the height above an arbitrary datum established at a streamgage, and (2) elevation, the height above the North American Vertical Datum of 1988 (NAVD 88).

Horizontal coordinate information is referenced to the North American Datum of 1983 (NAD 83). 



\title{
Flood-Inundation Maps for Grand River, Red Cedar River and Sycamore Creek near Lansing, Michigan
}

\author{
By Matthew T. Whitehead and Chad J. Ostheimer
}

\section{Abstract}

Digital flood-inundation maps for a total of 19.7 miles of the Grand River, the Red Cedar River, and Sycamore Creek were created by the U.S. Geological Survey (USGS) in cooperation with the City of Lansing, Michigan, and the U.S. Army Corps of Engineers. The flood-inundation maps, which can be accessed through the USGS Flood Inundation Mapping Science Web site at http://water.usgs.gov/osw/flood_inundation/, show estimates of the areal extent and depth of flooding corresponding to selected water levels (stages) at three USGS streamgages: Grand River at Lansing, MI (04113000), Red Cedar River at East Lansing, MI (04112500), and Sycamore Creek at Holt Road near Holt, MI (04112850). Near-real-time stages at these streamgages can be obtained on the Internet from the USGS National Water Information System at http:// waterdata.usgs.gov/ or the National Weather Service (NWS) Advanced Hydrologic Prediction Service at http:/water. weather.gov/ahps/, which also forecasts flood hydrographs at all of these sites.

Each set of flood profiles was computed by means of a one-dimensional step-backwater model. Each model was calibrated to the current stage-discharge relation at each streamgage and to water levels determined with stage sensors (pressure transducers) temporarily deployed along each stream reach. The hydraulic model was used to compute a set of water-surface profiles for flood stages from nearly Action Stage to above Major Flood stage, as reported by the National Weather Service. The computed water-surface profiles were then used in combination with a geographic Information System digital elevation model derived from light detection and ranging (lidar) data to delineate the approximate areas flooded at each water level.

These maps, used in conjunction with real-time USGS streamgage data and NWS forecasting, provide critical information to emergency management personnel and the public. This information is used to plan flood response actions, such as evacuations and road closures, as well as aid in postflood recovery efforts.

\section{Introduction}

Low-lying areas adjacent to the Grand River, the Red Cedar River, and Sycamore Creek in the Lansing, Michigan, area are subject to periodic flooding. A history of significant and repetitive flooding is well documented for these lowlying areas within central Lansing and East Lansing (City of Lansing, 2015). The City of Lansing estimates that about 1,700 residents and 250 businesses are at risk for flood damage (Ronda Oberlin, City of Lansing, oral commun, 2012).

Prior to this study, emergency responders near Lansing relied on several information sources to help make decisions on how to best alert the public and mitigate flood damages. One source is the Federal Emergency Management Agency (FEMA) flood insurance study (FIS) for Ingham County (Federal Emergency Management Agency, 2011). A second source is U.S. Geological Survey (USGS) streamgage data for the Grand River, the Red Cedar River, and Sycamore Creek, for which current (U.S. Geological Survey, 2015a, b, c) and historical (U.S. Geological Survey, 2015d) water levels and flows (including annual-peak flows) can be obtained. A third source of flood-related information is the National Weather Service (NWS) Advanced Hydrologic Prediction Service (AHPS), which displays the USGS stage data from the streamgages and also shows forecasted stages for each of the three streamgages (National Weather Service, 2015a, b, c).

Although the current stage at a USGS streamgage can be useful for residents in the immediate vicinity of a streamgage, it is less useful to residents farther upstream or downstream because the water-surface elevation is not constant along the entire stream reach. Knowledge of a water level at a streamgage is not easily translated into depth and areal extent of flooding at points distant from the streamgage. One way to address this problem is to produce a library of flood-inundation maps that are referenced to stages recorded at the USGS streamgages. By examining the appropriate maps, emergency responders can estimate projected severity of flooding (depth of water and areal extent), identify roads that are or may soon be flooded, and make plans for notification or evacuation 
of residents in harm's way for some distance upstream and downstream from the streamgage. In addition, visualizing the potential extent of flooding motivates residents to take precautions and heed warnings that might otherwise be disregarded.

\section{Purpose and Scope}

This report describes the development of a series of flood-inundation maps for the Grand River, the Red Cedar River, and Sycamore Creek near Lansing, Mich. (fig. 1). Report findings may also be downloaded for a total of 19.7 miles (mi) (table 1 ) of study reaches. The maps associated with this report were produced for flood levels referenced to 1-foot (ft) stages recorded at each of the three USGS streamgages (table 2) and have a range of near Action Stage to above Major Flood Stage (table 3) as designated by the National Weather Service (National Weather Service, 2015d).

For the remainder of this report, the USGS streamgage Grand River at Lansing, MI (04113000) will be referred to as the "Grand River streamgage." The Red Cedar River at East Lansing (04112500) streamgage will be referred to as the "Red Cedar River" streamgage, and the Sycamore Creek at Holt Road, near Holt, MI (04112850) will be referred to as the "Sycamore Creek streamgage."

Drainage areas were obtained from the NHD version 2 catchments (U.S. Environmental Protection Agency and U.S. Geological Survey, 2012), selected by tracing upstream from a point of interest. The catchment for a point of interest was clipped to remove downstream area by referencing USGS topographic maps for the appropriate area.

\section{Study Area Description}

Lansing is in the lower peninsula of Michigan, about $70 \mathrm{mi}$ north of the Ohio-Michigan State line. Lansing is mostly contained in the northwest corner of Ingham County, with a small portion in the county to the west, Eaton County. The largest river in Lansing is the Grand River, which bisects the city's downtown area. The Red Cedar River enters the Grand River just upstream (south) from the downtown area of Lansing. Sycamore Creek enters the Red Cedar River about 1 mi upstream (southeast) from the mouth of the Red Cedar River.

The drainage areas of the three streams include both rural and urban areas. Within the study limits of this project, the Grand River drainage is in an entirely urban area (Lansing), the Red Cedar River drainage is mostly urban (Lansing and East Lansing), and the Sycamore Creek drainage is mostly marshy wetlands.

\section{Previous Studies}

The current FIS for Ingham County, Michigan (Federal Emergency Management Agency, 2011) was published in 2011. Areas prone to major floods, corresponding to 10-, 2-, $1-$, and 0.2-percent annual chances of flooding (also referred to as the 10-, 50-, 100-, and 500-year floods) were redelineated as part of the revision of the FIS. The redelineations were based on topographic information developed using light detection and ranging (lidar) data collected in 2003. The 2011 FIS did not include any new hydrology or hydraulics, only a redelineation of the flood-plain boundaries on the newest (2003) topography.

The regulated flood elevations are based upon hydraulic data and hydrologic analyses completed in May 1978. In particular, field surveys of stream channels and bridge geometry reflect the conditions of more than 35 years ago. The topography of overbank areas was determined from topographic maps developed from aerial photography in 1978. These data were entered into a hydraulic model used to compute flood elevations based on flow values established from flood frequencymagnitude computations. These frequency-magnitude computations were themselves based on data available through 1978 at U.S. Geological Survey (2015a, b, c) streamgages Grand River at Lansing, MI (04113000), Red Cedar River at East Lansing, MI (04112500), and Sycamore Creek at Holt Road near Holt, MI (04112850).

As a result, the 2011 FIS report does not include updated hydraulic modeling to reflect changes in the natural channel and (or) hydraulic structures since 1978, nor does it include updated hydrologic analyses reflecting an additional 35 years of annual peak-flow data. Given the limitations of the FEMA 2011 FIS revision, the inundation maps for the Lansing area described in this report are based on a new hydraulic model incorporating data from new field surveys of the three stream channels, current geometries of hydraulic structures, and overbank geometry obtained from the latest Tri-County Regional Planning Commission lidar survey (2010). 


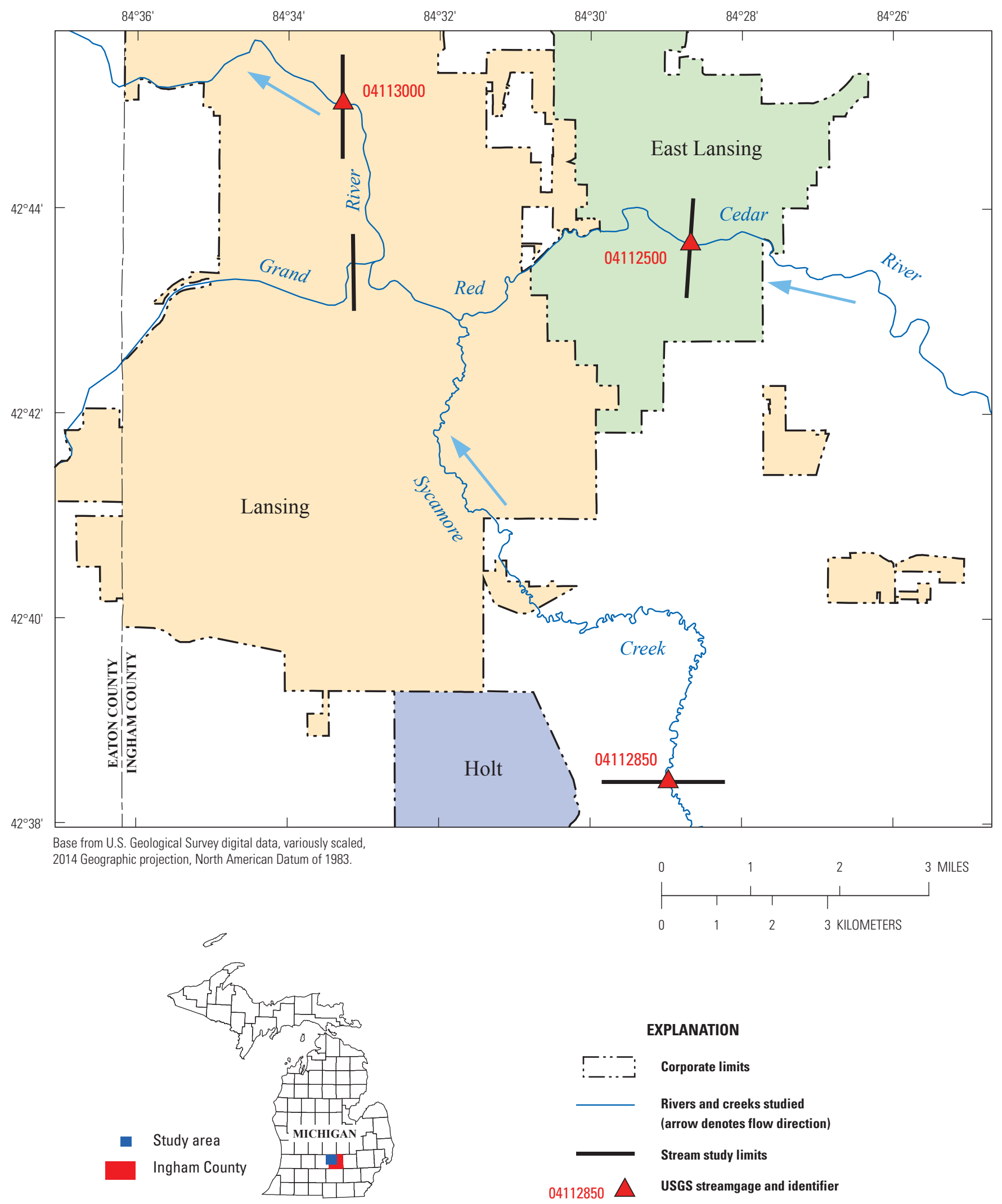

Figure 1. Locations of selected streamgages and rivers and creeks. 
Table 1. Description of study reaches.

\begin{tabular}{|c|c|c|c|}
\hline $\begin{array}{c}\text { River or } \\
\text { creek } \\
\text { name }\end{array}$ & $\begin{array}{c}\text { Reach } \\
\text { length } \\
\text { square mile }\end{array}$ & $\begin{array}{l}\text { Upstream } \\
\text { limit of study } \\
\text { reach }\end{array}$ & $\begin{array}{c}\text { Downstream } \\
\text { limit of study } \\
\text { reach }\end{array}$ \\
\hline Grand River & 2.3 & $\begin{array}{l}\text { South } \\
\text { Washington } \\
\text { Avenue bridge, } \\
\text { Lansing, } \\
\text { Michigan }\end{array}$ & $\begin{array}{l}\text { USGS } \\
\text { streamgage, } \\
\text { Grand River } \\
\text { at Lansing, } \\
\text { Michigan }\end{array}$ \\
\hline $\begin{array}{l}\text { Red Cedar } \\
\text { River }\end{array}$ & 5.4 & $\begin{array}{l}\text { USGS } \\
\text { streamgage, } \\
\text { Red Cedar } \\
\text { Creek at East } \\
\text { Lansing, } \\
\text { Michigan }\end{array}$ & $\begin{array}{l}\text { Mouth } \\
\text { (confluence } \\
\text { with Grand } \\
\text { River) }\end{array}$ \\
\hline $\begin{array}{c}\text { Sycamore } \\
\text { Creek }\end{array}$ & 12.0 & $\begin{array}{l}\text { USGS } \\
\text { streamgage, } \\
\text { Sycamore } \\
\text { Creek at Holt } \\
\text { Road near } \\
\text { Holt, Michigan }\end{array}$ & $\begin{array}{l}\text { Mouth } \\
\text { (confluence } \\
\text { with Red } \\
\text { Cedar River) }\end{array}$ \\
\hline
\end{tabular}

Table 3. Minimum and maximum target water-surface stages and National Weather Service designated stages for Grand River, Red Cedar River, and Sycamore Creek.

[ft, feet]

\begin{tabular}{|c|c|c|c|c|}
\hline $\begin{array}{c}\text { River or } \\
\text { creek } \\
\text { name }\end{array}$ & $\begin{array}{l}\text { Minimum } \\
\text { stage } \\
\text { included in } \\
\text { this report } \\
\text { (ft) }\end{array}$ & $\begin{array}{l}\text { Maximum } \\
\text { stage } \\
\text { included in } \\
\text { this report } \\
\text { (ft) }\end{array}$ & $\begin{array}{c}\text { Action } \\
\text { stage }^{1} \\
\text { (ft) }\end{array}$ & $\begin{array}{c}\text { Major } \\
\text { flood } \\
\text { stage }^{1} \\
\text { (ft) }\end{array}$ \\
\hline $\begin{array}{l}\text { Grand } \\
\text { River }\end{array}$ & 13.0 & 21.0 & 10.0 & 15.0 \\
\hline $\begin{array}{l}\text { Red Cedar } \\
\text { River }\end{array}$ & 8.0 & 14.0 & 7.0 & 10.5 \\
\hline $\begin{array}{c}\text { Sycamore } \\
\text { Creek }\end{array}$ & 6.0 & 11.0 & 6.0 & 10.0 \\
\hline
\end{tabular}

Table 2. U.S. Geological Survey streamgage information for the Grand River, the Red Cedar River, and Sycamore Creek near Lansing, Michigan.

[DA, drainage area; $\mathrm{mi}^{2}$, square miles; ft, feet; ft³/s, cubic feet per second; NAVD 88, North American Vertical Datum of 1988]

\begin{tabular}{|c|c|c|c|c|c|c|c|c|}
\hline $\begin{array}{l}\text { Station } \\
\text { name }\end{array}$ & $\begin{array}{l}\text { Station } \\
\text { number }\end{array}$ & $\begin{array}{c}\text { DA } \\
\left(\mathrm{mi}^{2}\right)\end{array}$ & Latitude & Longitude & $\begin{array}{l}\text { Period of } \\
\text { peak-flow } \\
\text { record }\end{array}$ & $\begin{array}{l}\text { Maximum } \\
\text { recorded } \\
\text { stage (ft) } \\
\text { and date }\end{array}$ & $\begin{array}{l}\text { Maximum } \\
\text { flows }\left(\mathrm{ft}^{3} / \mathrm{s}\right) \\
\text { and date }\end{array}$ & $\begin{array}{c}\text { Gage datum } \\
\text { (ft above } \\
\text { NAVD 88) }\end{array}$ \\
\hline $\begin{array}{l}\text { Grand River at } \\
\text { Lansing, MI }\end{array}$ & 4113000 & 1,230 & $42^{\circ} 45^{\prime} 02^{\prime \prime}$ & $84^{\circ} 33^{\prime} 19^{\prime \prime}$ & $1901-2014$ & $\begin{array}{c}18.60 \\
\text { Mar. 26, } 2004\end{array}$ & $\begin{array}{c}24,500 \\
\text { Mar. 26, } 2004\end{array}$ & 804.92 \\
\hline $\begin{array}{l}\text { Red Cedar } \\
\text { River at East } \\
\text { Lansing, MI }\end{array}$ & 4112500 & 344 & $42^{\circ} 43^{\prime} 38^{\prime \prime}$ & $84^{\circ} 28^{\prime} 41^{\prime \prime}$ & $\begin{array}{l}1903-1904 \\
1911-2014\end{array}$ & $\begin{array}{c}13.40 \\
\text { Mar. 24, } 2004\end{array}$ & $\begin{array}{c}8,000^{1} \\
\text { Mar. 24, } 2004\end{array}$ & 823.96 \\
\hline $\begin{array}{c}\text { Sycamore Creek } \\
\text { at Holt Road, } \\
\text { near Holt, MI }\end{array}$ & 4112850 & 80 & $42^{\circ} 38^{\prime} 25^{\prime \prime}$ & $84^{\circ} 28^{\prime} 58^{\prime \prime}$ & 1975-1997 & $\begin{array}{c}10.00 \\
\text { Apr. } 19,1975\end{array}$ & $\begin{array}{c}2,110 \\
\text { Apr. } 19,1975\end{array}$ & 844.89 \\
\hline
\end{tabular}

${ }^{1}$ Flow is an estimate. 


\section{Creation of Flood-Inundation-Map Library}

The USGS has standardized the procedures for creating flood-inundation maps for flood-prone communities (U.S. Geological Survey, 2015e) so that the process followed and products produced are similar regardless of which USGS office is responsible for the work. Tasks specific to development of the flood maps were (1) reestablishment of one streamgage (table 1) on Sycamore Creek, (2) collection of topographic and bathymetric data for selected cross sections and geometric data for structures and bridges along each study reach, (3) estimation of energy-loss factors (roughness coefficients) in the stream channel and flood plain, (4) computation of water-surface profiles using the U.S. Army Corps of Engineers' Hydrologic Engineering Center - River Analysis System (HEC-RAS) computer program (U.S. Army Corps of Engineers, 2010), (5) production of flood-inundation maps corresponding to selected stream stages by use of the U.S. Army Corps of Engineers' HEC-GeoRAS computer program (U.S. Army Corps of Engineers, 2009) and a geographic information system (GIS), and (6) preparation of map products for a USGS floodinundation mapping application that show the areal extent of flooding and water depths for display on a USGS floodinundation mapping application.

\section{Computation of Water-Surface Profiles}

The water-surface profiles used to produce the floodinundation maps in this study were computed by using HEC-RAS, version 4.1.0 (U.S. Army Corps of Engineers, 2010). HEC-RAS is a one-dimensional step-backwater model used for simulation of water-surface profiles with steady-state (gradually varied) or unsteady-state flow computation options.

\section{Hydrologic Data}

The study reaches include three streamgages (table 2). Two of the gages were already in operation with continuous recorders, and one streamgage (Sycamore Creek) was reestablished for this project. Stage is measured every 15 minutes, transmitted hourly by a satellite radio in the streamgage, and made available on the Internet through the USGS National Water Information System (NWIS; U.S. Geological Survey, 2015a, b, c).

For each streamgage, the current ${ }^{1}$ stage-discharge relation (rating) was used to determine the flow for each study reach corresponding to the target stage value. For each stream, the rating (table 4) was extended (using HEC-RAS) to include target stages higher than the current rating provided. Because the streamgages for the Red Cedar River and Sycamore Creek are at the upstream ends of their respective study reaches,

${ }^{1}$ At the time of this report, the current rating for Grand River is 15.0, Red Cedar is 16.0 and Sycamore Creek is 6.0. streamflows were increased at selected downstream locations (fig. 2) to account for the gradual increase in drainage-area size (table 5). Because there are no drainage-area-only equations for peak flows at ungagged locations in Michigan, a straight drainage-area ratio was used to compute increases in discharge downstream of the gages. In addition, the streamflows for the Red Cedar River below Sycamore Creek were increased to include inflows corresponding to the various target stages of Sycamore Creek. Because the Grand River streamgage is at the downstream end of its study reach, streamflows were decreased above the Red Cedar River to account for inflows corresponding to the various target stages of the Red Cedar River.

\section{Topographic and Bathymetric Data}

Cross-section elevation data were obtained from a digital elevation model (DEM) that was derived from lidar data collected during March 2010. The original lidar data have horizontal resolution of $3.8 \mathrm{ft}$ (1.2 meters) and vertical accuracy of $0.49 \mathrm{ft}$ ( 15 centimeters) at a 95-percent confidence level for the "open terrain" land-cover category. By these criteria, the lidar data support production of 2 -ft contours (Dewberry, 2012). The 4- by 4-ft-resolution DEM was provided to the USGS by the Tri-County Regional Planning Commission (2010), and the USGS created 1-ft contour lines from the DEM data using ArcGIS.

By using HEC-GeoRAS (USACE, 2009) - a set of procedures, tools, and utilities for processing geospatial data in ArcGIS - elevation data were extracted from the DEM for 422 cross sections and input to the HEC-RAS model. The cross-sectional spacing is $210 \mathrm{ft}$ on average, and the maximum distance between sections is $497 \mathrm{ft}$.

Because standard lidar data do not provide ground elevations below a stream's water surface, channel cross sections were surveyed by USGS field crews during 2013. Crosssectional depths were measured by conventional (total station) surveying techniques or by using hydroacoustic instrumentation at 176 locations. A differential global positioning system (DGPS) with realtime kinematic (RTK) technology was used to derive horizontal locations and the elevation of the water surface at each surveyed cross section. Elevations determined by RTK DGPS at six benchmark locations were within $0.02-0.13 \mathrm{ft}$ of the known elevations, an error range that is better than the accuracy of the lidar data.

DEM-generated cross sections were colocated with the locations of the within-channel field-surveyed cross sections. In these cases, within-channel data were directly merged with the DEM data. For all other cross sections, the within-channel data were estimated by interpolation from the closest field-surveyed cross section. In-channel data were surveyed upstream and downstream from every hydraulic structure. Additional cross sections were surveyed to ensure that no reach length between surveyed cross sections was greater than $1 \mathrm{mi}$. 
Table 4. Selected stages and associated streamflows for respective stage-discharge relations for the Grand River, Red Cedar River, and Sycamore Creek streamgages referred to in this report.

[ft, feet; $\mathrm{ft}^{3}$, cubic feet per second; bolded values indicate data that exceed the range of the current ratings ${ }^{1}$ ]

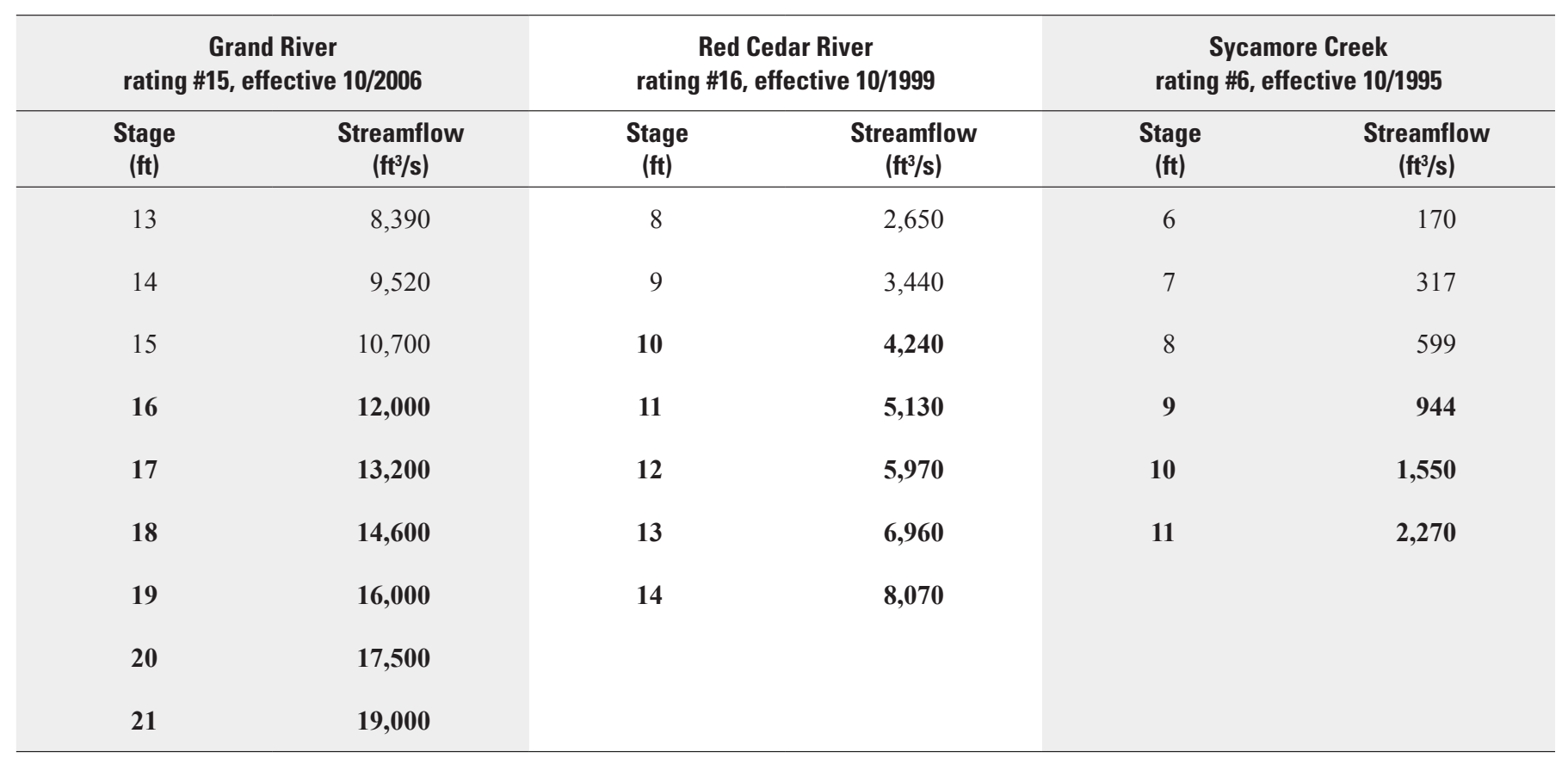

${ }^{1}$ At the time of this report, the current rating for Grand River is 15.0, Red Cedar is 16.0 and Sycamore Creek is 6.0.

Table 5. Drainage areas at selected locations for the Red Cedar River and Sycamore Creek.

[DA, drainage area]

\begin{tabular}{|c|c|c|c|}
\hline Location & $\begin{array}{c}\text { River } \\
\text { station }^{1}\end{array}$ & $\begin{array}{c}\text { DA } \\
\text { (square } \\
\text { miles) }\end{array}$ & $\begin{array}{c}\text { Percentage } \\
\text { of DA } \\
\text { (percent) }\end{array}$ \\
\hline \multicolumn{4}{|c|}{ Red Cedar River } \\
\hline Streamgage & 28,300 & 344 & 100.0 \\
\hline Below Kalamazoo Street & 17,485 & 349 & 101.5 \\
\hline Below Sycamore Creek & 7,805 & 459 & 133.4 \\
\hline \multicolumn{4}{|c|}{ Sycamore Creek } \\
\hline Streamage & 63,320 & 80.0 & 100.0 \\
\hline Below College Road & 43,256 & 83.9 & 104.9 \\
\hline $\begin{array}{l}\text { Below unnamed tributary from } \\
\text { west }\end{array}$ & 21,586 & 88.1 & 110.1 \\
\hline
\end{tabular}

${ }^{1}$ River stations are referenced to the longitudinal baseline used in the hydraulic model, referenced to the mouth.

\section{Hydraulic Structures}

Along the selected stream reaches, there are 43 structures (road crossings, railroad bridges, and walk paths) and 2 dams that may affect water-surface elevations during floods. Structure-geometry data were obtained from field surveys conducted by personnel from the USGS Michigan-Ohio Water Science Center using RTK DGPS and conventional surveying techniques.

It should be noted that the North Lansing Dam (fig. 3), which is maintained and operated by the Lansing Board of Water and Light, has multiple (manually operated) gate settings that affect water-surface elevations. The dam has four gates that are usually positioned in one of three configurations: (1) all gates up, (2) gate 1 down with gates 2, 3, and 4 up, and (3) all gates down (Jessica Harbitz, Lansing Board of Water and Light, written commun., 2012). At the request of the study partners, and assuming a "worst-case scenario" with respect to flood elevations, all hydraulic modeling (and subsequent flood-plain delineations) included in this report reflect only the configuration of all gates up (closed). 


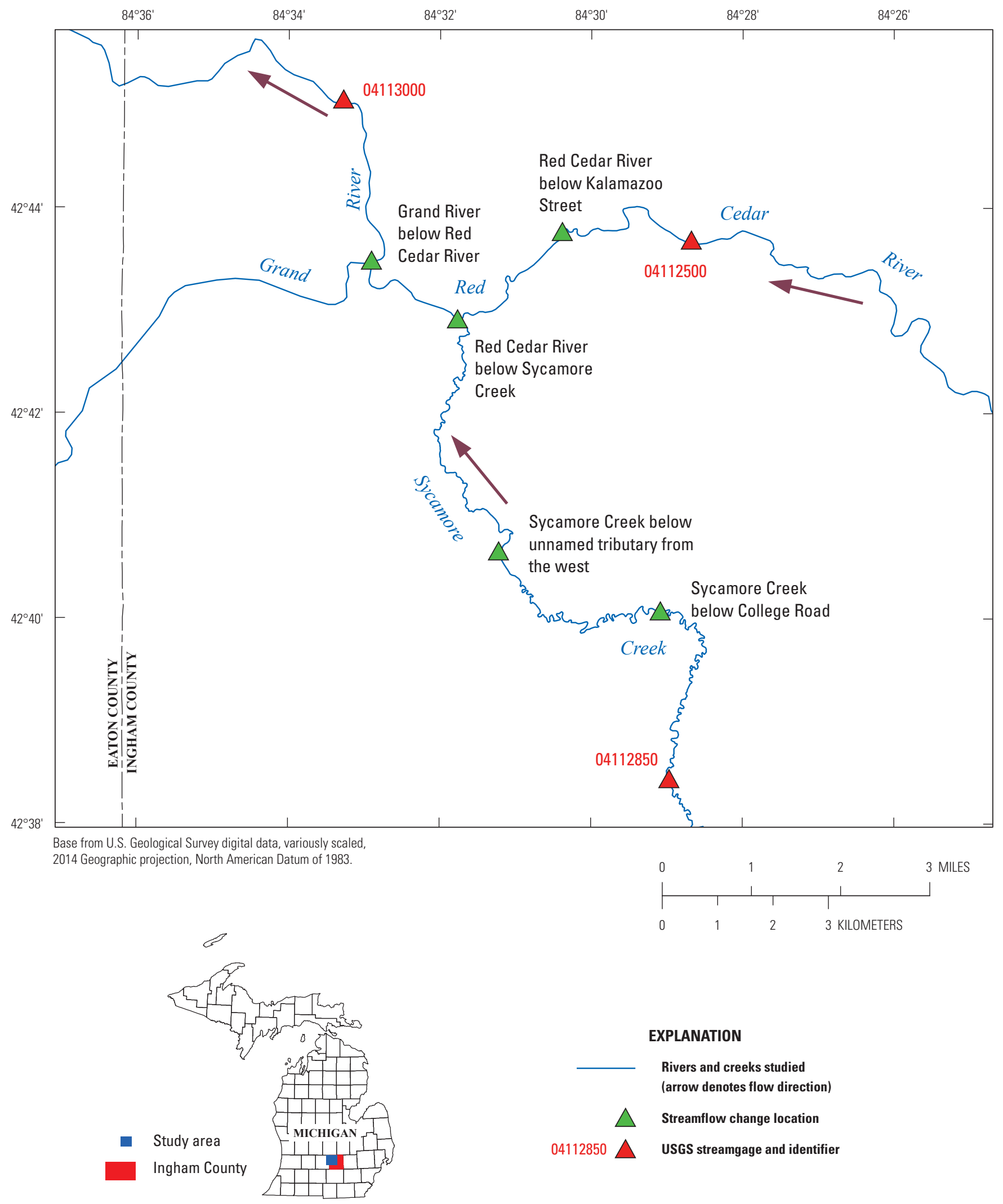

Figure 2. Locations of increased flows due to increased drainage area. 


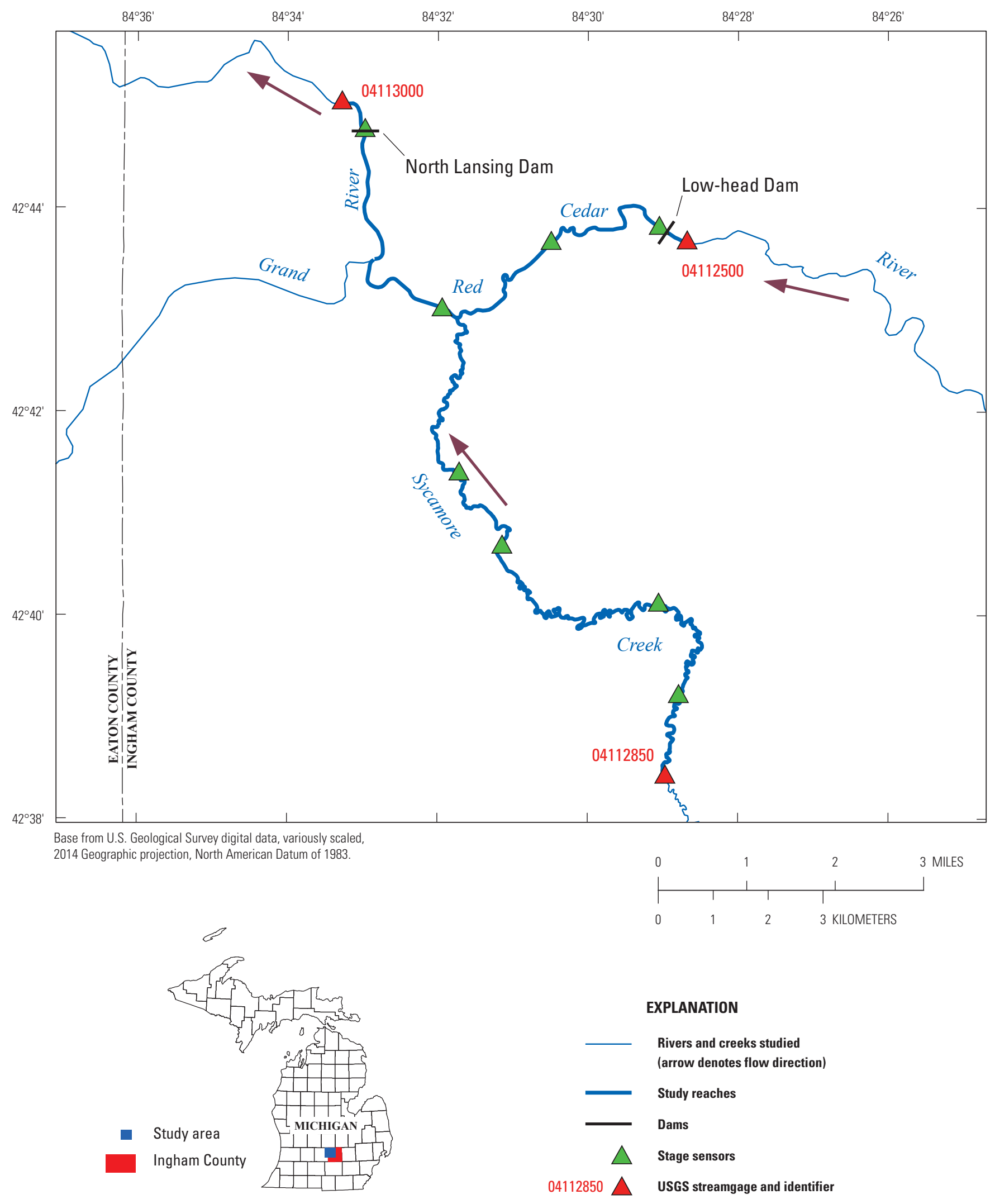

Figure 3. Locations of selected USGS streamgages and stage sensors near Lansing, Michigan. 


\section{Energy-Loss Factors}

Hydraulic analyses require the estimation of energy losses exerted by a channel on flow. These energy losses are quantified by the Manning's roughness coefficient (" $n$ " value). Initial (precalibration) $n$ values were selected on the basis of field observations and high-resolution aerial photographs.

As part of the calibration process, the initial $n$ values were adjusted until the differences between computed and observed water-surface elevations at the streamgage and stage sensors were minimized. The final $n$ values ranged from 0.040 to 0.048 for the main channels and 0.036 to 0.100 for the overbank areas modeled in this analysis (table 6).

\section{Hydraulic Model}

The HEC-RAS analysis for this study was done by using the steady-state flow computation option. Steady-state flow data consisted of flow regime, boundary conditions, and peak flows that produced water-surface elevations at the streamgage cross section that matched target water-surface elevations. These target elevations (table 7) coincided with $1 \mathrm{ft}$ increments of stage. A subcritical (tranquil) flow regime was assumed for the simulations. The Grand River streamgage is at the downstream end of the study reach, so the boundary condition is a known water-surface elevation, with the values taken from the current rating for the streamgage for each profile. The peak flows that were used in the model were discussed in the section, "Hydrologic Data."

The Red Cedar River is subject to backwater conditions from the Grand River. Sycamore Creek is subject to backwater

Table 6. Range in Manning's roughness factors for selected streams.

\begin{tabular}{lcc}
\hline \multicolumn{1}{c}{ Stream } & $\begin{array}{c}\text { Manning's } \boldsymbol{n} \\
\text { for main channel }\end{array}$ & $\begin{array}{c}\text { Manning's } \boldsymbol{n} \\
\text { for overbank areas }\end{array}$ \\
\hline Grand River & $0.040-0.042$ & $0.040-0.062$ \\
Red Cedar River & $0.040-0.046$ & $0.036-0.090$ \\
Sycamore Creek & $0.042-0.048$ & $0.042-0.100$ \\
\hline
\end{tabular}

conditions from both the Grand and Red Cedar Rivers. To account for concurrent flooding from multiple streams, the hydraulic model joined the three streams together by means of junctions. As a result, the model used water-surface elevations from the Grand River as downstream boundary conditions for the Red Cedar River and used water-surface elevations from the Red Cedar River as downstream boundary conditions for Sycamore Creek.

\section{Model Calibration}

In addition to the target stages at each of the three streamgages, calibration information was obtained by installing stage sensors (pressure transducers) at eight locations along the modeled reaches of the three streams (fig. 3 ) in March 2014. Surveys were conducted to establish the vertical datum of each stage sensor relative to NAVD 88 . The stage sensor elevations were checked, data were downloaded, and the sensors were cleaned twice during their deployment. The stage sensors were removed in July 2014.

Stage data collected during a runoff event in May 2014 provided additional data for model calibration. Streamflow values used to calibrate the HEC-RAS model for the event were obtained from the current rating for each streamgage. After calibration, the modeled elevations and measured elevations (from sensors and streamgages) had a root mean square error of $0.29 \mathrm{ft}$, with a maximum difference of $0.61 \mathrm{ft}$ (table 8). For reference, this runoff event had the following stages at each of the three stream gages: Grand River, $9.1 \mathrm{ft}$; Red Cedar River, $7.3 \mathrm{ft}$; and Sycamore Creek, $8.1 \mathrm{ft}$.

Table 7. Calibration of model to target water-surface elevations at selected U.S. Geological Survey streamgages.

[ft, feet; NAVD 88, North American Vertical Datum of 1988]

\begin{tabular}{cccc}
\hline $\begin{array}{c}\text { Stage of } \\
\text { water-surface } \\
\text { profile } \\
\text { (ft) }\end{array}$ & $\begin{array}{c}\text { Target } \\
\text { water-surface } \\
\text { elevation } \\
\text { (ft, NAVD 88) }\end{array}$ & $\begin{array}{c}\text { Modeled } \\
\text { water-surface } \\
\text { elevation } \\
\text { (ft, NAVD 88) }\end{array}$ & $\begin{array}{c}\text { Difference } \\
\text { in elevation } \\
\text { (ft) }\end{array}$ \\
\hline \multicolumn{4}{c}{ Red Cedar River } \\
\hline 8 & 831.96 & 832.11 & 0.15 \\
9 & 832.96 & 833.05 & 0.09 \\
\hline 6 & Sycamore Creek & \\
\hline 7 & 850.89 & 850.70 & 0.19 \\
\hline 8 & 851.89 & 851.91 & -0.02 \\
\hline
\end{tabular}


Table 8. Calibration of model to water-surface elevations at selected locations along selected streams for the flood of May 16, 2014.

[ft, feet; NAVD 88, North American Vertical Datum of 1988]

\begin{tabular}{|c|c|c|c|c|}
\hline Lansing Streamgage & 68 & 814.02 & 814.02 & 0.00 \\
\hline Stage sensor & 3,016 & 817.41 & 817.68 & 0.27 \\
\hline Stage sensor & 6,892 & 821.88 & 821.78 & -0.10 \\
\hline Stage sensor & 16,321 & 825.12 & 824.81 & -0.31 \\
\hline Stage sensor & 26,639 & 829.96 & 830.02 & 0.06 \\
\hline Stage sensor & 21,586 & 835.40 & 834.88 & -0.52 \\
\hline Stage sensor & 43,387 & 844.11 & 843.50 & -0.61 \\
\hline Stage sensor & 55,176 & 848.26 & 848.21 & -0.05 \\
\hline Holt Road streamgage & 63,320 & 853.00 & 853.07 & 0.07 \\
\hline
\end{tabular}

${ }^{1}$ River station numbers are referenced to the longitudinal baseline used in the hydraulic model, referenced to the mouth.

\section{Selection of Final Flood Profiles}

The total number of possible combinations of profiles is the product of the 9 stages for the Grand River (table 4), 7 for the Red Cedar River, and 6 for Sycamore Creek, or 378 possible combinations. The flow values from table 4 were analyzed to determine combinations that would be likely to occur. Of the 378 combinations, 8 represent combinations where the sum of discharges from the Red Cedar River and Sycamore Creek exceed the total flow in the Grand River. For example, the combination of stage 14 (Red Cedar River) and stage 11 (Sycamore Creek) represent a combined discharge of $10,340 \mathrm{ft} 3 / \mathrm{s}$, which exceeds the $8,390 \mathrm{ft} 3 / \mathrm{s}$ associated with stage 13 on the Grand River - and, therefore, is an illogical combination (assuming no storage). Removing these 8 illogical combinations leaves 370 possible combinations.

Coincident peak-flow data were obtained from multiple sources for all three stream gages and analyzed (fig. 4). Most data were obtained from USGS records; however, some data were obtained from the National Weather Service (National Weather Service, 2015a, b, c ).

The highest percentage of flow from the Red Cedar River and Sycamore Creek to flow in the Grand River occurred in 1975 at 72 percent. The highest percentage of flow from Sycamore Creek to flow in the Red Cedar River occurred in 1979 at 59 percent. Final flood profiles for this report include combinations (flow distributions) where (1) the sum of flows of the Red Cedar River and Sycamore Creek was less than 72 percent of the flow for the Grand River and (2) the flow for Sycamore Creek was less than 59 percent of the flow for the Red Cedar River. This resulted in a total of 305 profiles. (See appendix 1 for a table of modeled stage combinations.)

\section{Development of Flood-Inundation Maps}

A method was devised to map calculated flood-plain boundaries corresponding to each of the 305 final profiles, resulting in approximated flood-plain boundaries. For each set of two adjacent cross sections in a given profile, an average water-surface elevation was calculated and rounded to the nearest foot. This water-surface elevation was then represented by the topo line between adjacent sections. An example of an approximated flood profile for the Grand River is shown in figure 5 .

An error analysis of this approximate mapping method showed that, as expected, the maximum and minimum errors between the average water-surface elevation and those rounded to the nearest whole foot were $0.50 \mathrm{ft}$ and $-0.50 \mathrm{ft}$, respectively. The average and average absolute errors were $0.00 \mathrm{ft}$ and $0.25 \mathrm{ft}$, respectively. This analysis indicates that, on average, the approximately mapped water-surface elevation is within $0.25 \mathrm{ft}$ of the average water-surface elevation or $1 / 4$ of the base mapping contour interval and the mapped stage interval. 


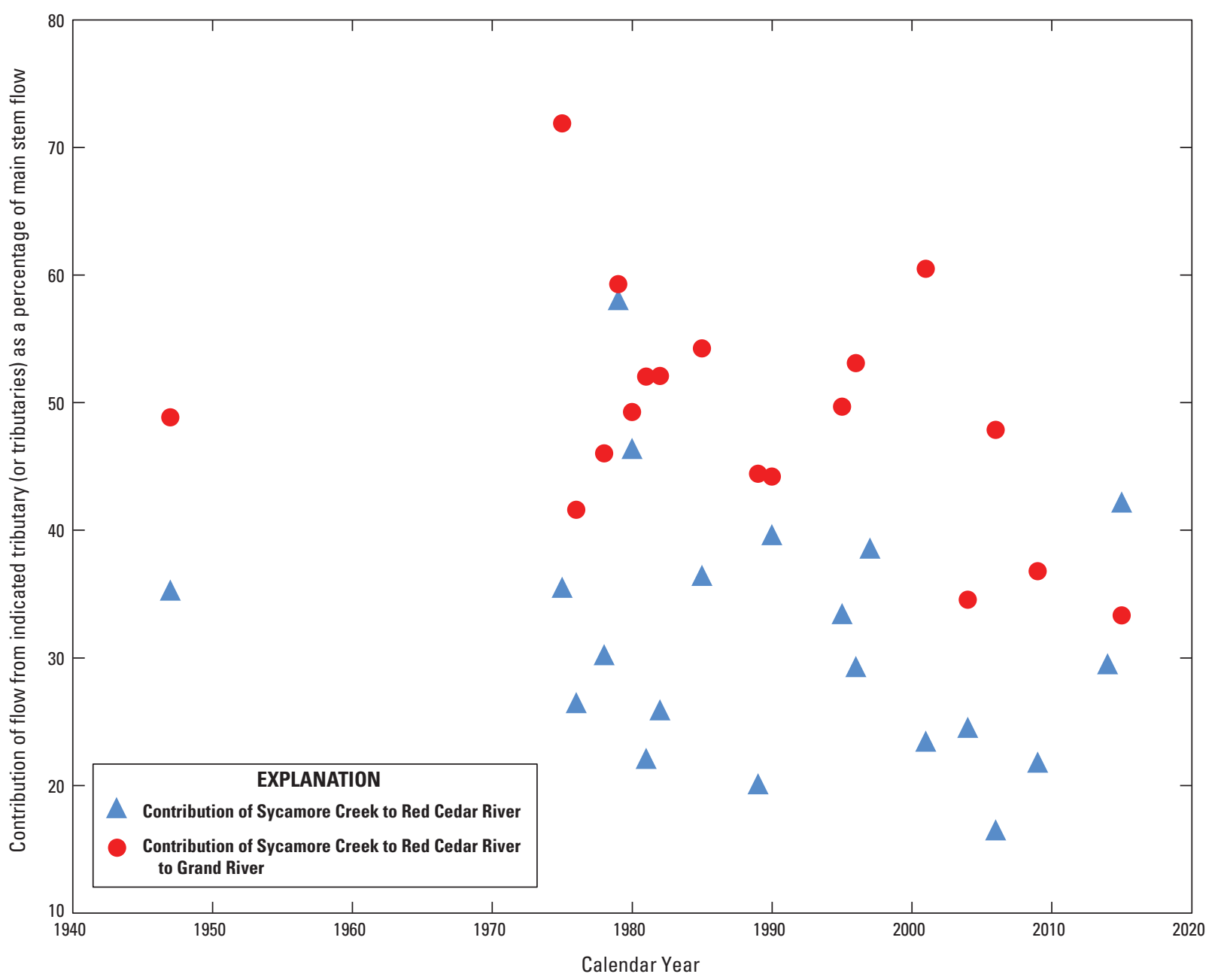

Figure 4. Percentages of tributary flows to main stem flows for selected streams near Lansing, Michigan

In order to create the approximate flood-plain boundaries for the flood profiles, the contours created from the DEM provided (see "Topographic and Bathymetric Data" section) that matched the rounded elevation for each set of adjacent cross sections were selected to produce the flood-plain boundary for each adjacent cross-section segment. The segments were then combined to produce a continuous flood-plain boundary. The amount of longitudinal error for the flood-plain boundaries (fig. 5) for the approximated water-surface elevation varies depending on the width of separation for adjacent topographic lines. The flood-plain boundaries resulting from mapping the approximated water-surface elevations can show (depending on the scale at which the mapping is viewed) disjointed edges or "jumps" in the flood-plain boundaries. Figure 5 shows an example of the estimated flood-plain boundary "jumping" as the approximated water-surface elevation changes from $828 \mathrm{ft}$ to $829 \mathrm{ft}$. No error analyses were conducted for the longitudinal errors of the "jumps" along the edges of the flood-plain boundaries.
After the flood-plain boundaries for the approximated flood profiles were created, checks were performed to ensure logical transitions. Any inundated areas that were detached from the main channel were examined to identify artificial connections with the main rivers, such as through culverts under roadways. Where such connections existed, the mapped inundated areas were retained in their respective flood maps; otherwise, the disconnected inundation areas were deleted. The flood-inundation areas were superimposed on highresolution, georeferenced aerial photographs of the study area. Bridge surfaces are not shown as being inundated until a flood stage is reached that either intersects the lowest structural chord of the bridge or completely inundates one or both approaches to the bridge. Estimates of water depths can be determined from the depth-grid data that are included with the flood-inundation maps on the USGS mapping application described in the following section, "Flood-Inundation Map Delivery." 

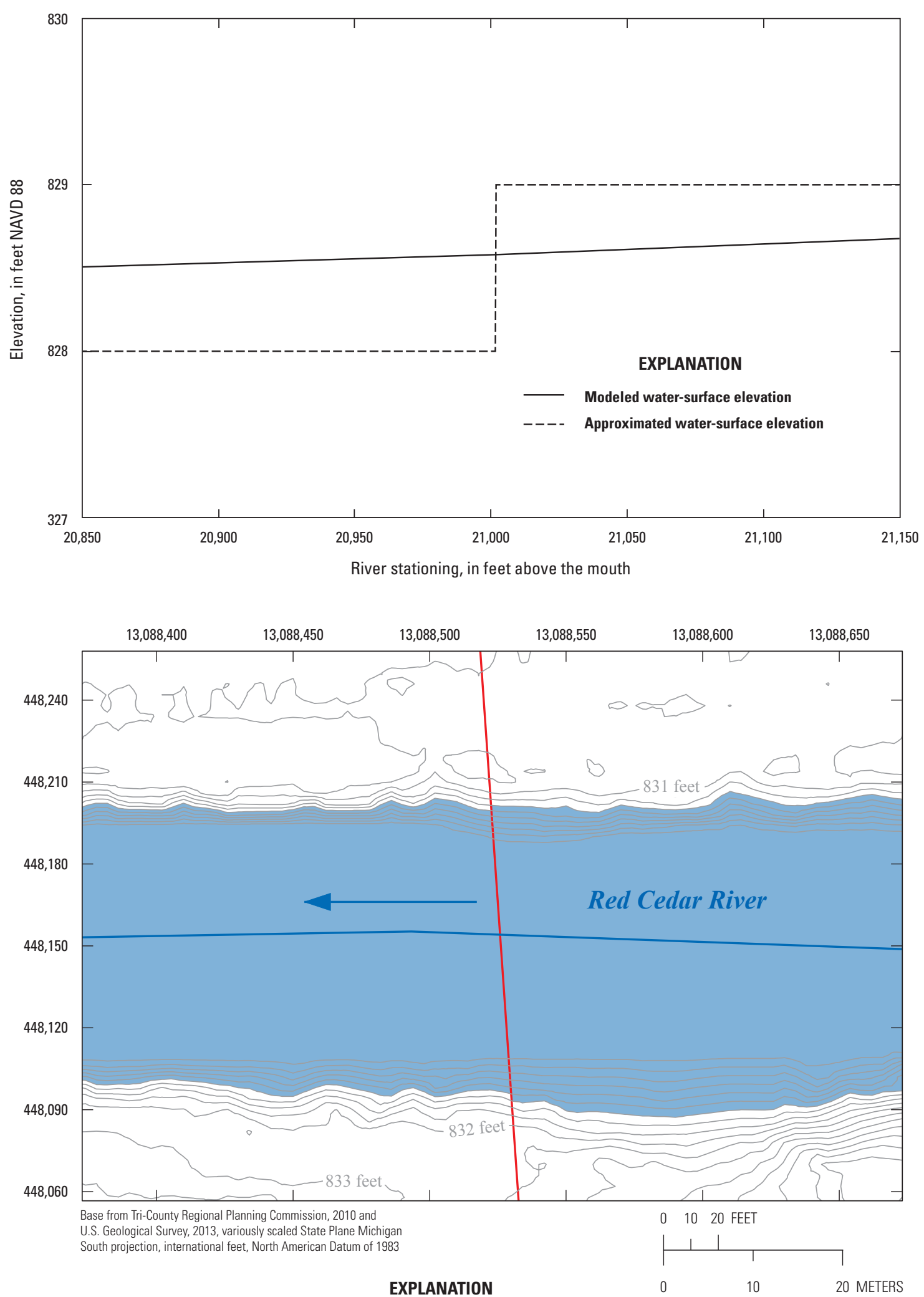

Approximated flood-plain boundary

Elevation contours
Red Cedar River (arrow denotes flow direction)

Hydraulic model cross section

Figure 5. Modeled and approximated water-surface profile for Red Cedar River. 


\section{Flood-Inundation Map Delivery}

A Flood Inundation Mapping Science Web site (U.S. Geological Survey, 2015e) was established to deliver USGS flood-inundation study information to the public. The site links to a mapping application that presents map libraries and provides detailed information on flood extents and depths for modeled sites. The mapping application enables the production of customized flood-inundation maps from the map library for each of the three streamgages. A link on this Web site connects to the USGS National Water Information System (U.S. Geological Survey, 2015a, b, c), which presents the current stage and streamflow at each of the USGS streamgages to which the inundation maps are referenced. A second link connects to the NWS Advanced Hydrologic Prediction Service (AHPS) site (National Weather Service, 2015a, b, c) so that the user can obtain applicable information on forecasted peak. The estimated flood-inundation maps are displayed in sufficient detail so that preparations for flooding and decisions for emergency response can be performed efficiently. Depending on the flood magnitude, roadways are shown as shaded (inundated and likely impassable) or not shaded (dry and passable) to facilitate emergency planning and use. A shaded building should not be interpreted to mean that the structure is completely submerged but rather that bare-earth surfaces in the vicinity of the building are inundated. In these instances, the water depth (as indicated in the mapping application by holding the cursor over an inundated area) near the building would be an estimate of the water level inside the structure, unless floodproofing measures had been implemented.

\section{Disclaimer for Flood-Inundation Maps}

The flood-inundation maps should not be used for navigation, regulatory, permitting, or other legal purposes. The USGS provides these maps "as-is" for a quick reference, emergency planning tool but assumes no legal liability or responsibility resulting from the use of this information.

\section{Uncertainties and Limitations Regarding Use of Flood-Inundation Maps}

Although the flood-inundation maps represent the boundaries of inundated areas with a distinct line, some uncertainty is associated with these maps. The flood boundaries shown were estimated on the basis of water stages and streamflows at selected USGS streamgages. Water-surface elevations along the stream reaches were estimated by steady-state hydraulic modeling, assuming unobstructed flow, and using streamflows and hydrologic conditions anticipated at the USGS streamgages. The hydraulic model reflects the land-cover characteristics and any bridge, dam, levee, or other hydraulic structures existing as of January 2015. Unique meteorological factors (timing and distribution of precipitation) may cause actual streamflows along the modeled reach to vary from those assumed during a flood, which may lead to deviations in the water-surface elevations and inundation boundaries shown. Additional areas may be flooded due to unanticipated conditions such as changes in the streambed elevation or roughness, backwater into major tributaries along a main stem river, or backwater from localized debris or ice jams. The accuracy of the floodwater extent portrayed on these maps will vary with the accuracy of the digital elevation model used to simulate the land surface.

If this series of flood-inundation maps will be used in conjunction with National Weather Service (NWS) river forecasts, the user should be aware of additional uncertainties that may be inherent or factored into NWS forecast procedures. The NWS uses forecast models to estimate the quantity and timing of water flowing through selected stream reaches in the United States. These forecast models (1) estimate the amount of runoff generated by precipitation and snowmelt, (2) simulate the movement of floodwater as it proceeds downstream, and (3) predict the flow and stage (and water-surface elevation) for the stream at a given location (AHPS forecast point) throughout the forecast period (every 6 hours and 3 to 5 days out in many locations). For more information on AHPS forecasts, please see http://water.weather.gov/ahps/pcpn_and river_forecasting.pdf. Additional uncertainties and limitations pertinent to this study are described elsewhere in this report.

The hydraulic modeling and subsequent mapping of flood-plain boundaries assumed coincident flood peaks for the three streams studied. Actual flood-peak timing is dependent upon factors not limited to drainage-area size, slope, storage, and precipitation patterns. Coincident flood-peak timings were chosen to represent more conservative flooding scenarios. If the peak flood timing of the three streams is not coincident, the actual flooding boundaries may be different than those represented in this study.

\section{Summary}

The U.S. Geological Survey (USGS), in cooperation with the City of Lansing, Michigan, and U.S. Army Corps of Engineers, developed a series of digital flood-inundation maps showing estimates of the areal extent and depth of flooding corresponding to selected water levels (stages) at three USGS streamgages: Grand River at Lansing, MI (04113000), Red Cedar River at East Lansing, MI (04112500), and Sycamore Creek at Holt Road near Holt, MI (04112850). Altogether, the mapped areas include 19.7 stream miles. The U.S. Army Corps of Engineers' HEC-RAS and HEC-GeoRAS programs were used to compute water-surface profiles and to help delineate estimated flood-inundation areas and depths of flooding for selected stream stages. The HEC-RAS hydraulic model was calibrated to the current stage-discharge relation at each streamgage and to water-level data measured with pressure transducers during a runoff event in May 2014. The model was used to compute water-surface profiles for flood stages from nearly Action Stage to above Major Flood Stage, as reported 
by the National Weather Service. The computed water-surface profiles were then used in combination with a digital elevation model (DEM), derived from light detection and ranging (lidar) data to delineate estimated flood-inundation areas and depth grids. These flood-inundation areas were superimposed on high-resolution, georeferenced aerial photographs of the study area. The flood maps are available through a mapping application that can be accessed on the USGS Flood Inundation Mapping Science Web site (http://water.usgs.gov/osw/ flood inundation).

Interactive use of the maps on this mapping application can give users a general indication of depth of water at any point by using the mouse cursor to click within the shaded areas. These maps, in conjunction with the real-time stage data from the USGS streamgages, and forecasted flood stage data from the National Weather Service Advanced Hydrologic Prediction Service can help emergency planners and the public make more informed decisions about flood risk.

\section{References Cited}

City of Lansing [Michigan], 2015, Flooding: City of Lansing Web page, accessed May 11, 2015, at http://www.lansingmi. gov/floods.

Dewberry, 2012, National Enhanced Elevation Assessment: Fairfax, Va., 84 p., accessed July 9, 2013, at http:// www.dewberry.com/files/pdf/NEEA_Final\%20Report Revised\%203.29.12.pdf.

Federal Emergency Management Agency, 2011, Flood Insurance Study for Ingham County, Michigan (All Jurisdictions): Flood Insurance Study Number 26065CV000A, $93 \mathrm{p}$.

National Weather Service, 2015a, Advanced Hydrologic Prediction Service, Grand River at Lansing, accessed January 5, 2015, at http://water.weather.gov/ahps2/hydrograph. $\mathrm{php}$ ? wfo $=$ grr\&gage $=\operatorname{lnsm} 4$.

National Weather Service, 2015b, Advanced Hydrologic Prediction Service, Red Cedar River at East Lansing, accessed January 5, 2015, at http://water.weather.gov/ahps2/ hydrograph.php?wfo=grr\&gage $=\operatorname{elnm} 4$.

National Weather Service, 2015c, Advanced Hydrologic Prediction Service, Sycamore Creek near Holt, accessed January 5, 2015, at http://water.weather.gov/ahps2/hydrograph. php? wfo $=$ grr\&gage $=$ hhtm 4 .
National Weather Service, 2015d, Advanced Hydrologic Prediction Service, High water level terminology, accessed January 5, 2015, at http://aprfc.arh.noaa.gov/resources/docs/ floodterms.php.

Tri-County Regional Planning Commission-Clinton, Ingham, and Eaton Counties, Michigan, 2010, Aerial imagery, LiDAR capture, and digital elevation model.

U.S. Army Corps of Engineers, Hydrologic Engineering Center, 2009, HEC-GeoRAS, GIS Tools for Support of HEC-RAS using ArcGIS-User's manual, version 4.2 [variously paged].

U.S. Army Corps of Engineers, Hydrologic Engineering Center, 2010, HEC-RAS River Analysis System, Hydraulic reference manual, version 4.1 [variously paged].

U.S. Environmental Protection Agency and U.S. Geological Survey, 2012, National Hydrography Dataset Plus-NHDPlus version 2.1, accessed July 2014 at http:// www.horizon-systems.com/NHDPlus/NHDPlusV2_home. php.

U.S. Geological Survey, 2015a, USGS 04113000 Grand River at Lansing, MI: U.S. Geological Survey National Water Information System, accessed January 5, 2015, at http:// waterdata.usgs.gov/mi/nwis/uv?site_no $=04113000$.

U.S. Geological Survey, 2015b, USGS 04112500 Red Cedar River at East Lansing, MI: U.S. Geological Survey National Water Information System, accessed January 5, 2015, at http://waterdata.usgs.gov/mi/nwis/uv?site_no $=04112500$.

U.S. Geological Survey, 2015c, USGS 04112850 Sycamore Creek at Holt Road near Holt, MI: U.S. Geological Survey National Water Information System, accessed January 5, 2015, at http://waterdata.usgs.gov/mi/nwis/uv?site_ no $=04112850$.

U.S. Geological Survey, 2015d, USGS surface-water data for the Nation: U.S. Geological Survey National Water Information System, accessed January 5, 2015, at http:// waterdata.usgs.gov/nwis/sw.

U.S. Geological Survey, 2015e, USGS Flood Inundation Mapping Science: U.S. Geological Survey, accessed January 5, 2015, at http://water.usgs.gov/osw/flood_inundation. 


\section{Appendix 1}

\section{Appendix 1}

Modeled stage combinations for Grand River, Red Cedar River, and Sycamore Creek. 
Appendix 1. Modeled stage combinations for Grand River, Red Cedar River, and Sycamore Creek.

[Combinations (total of 305) were generated by holding stage constant for two of the three streams and varying stage for the third by 1-foot increments for the range of stages selected for this study]

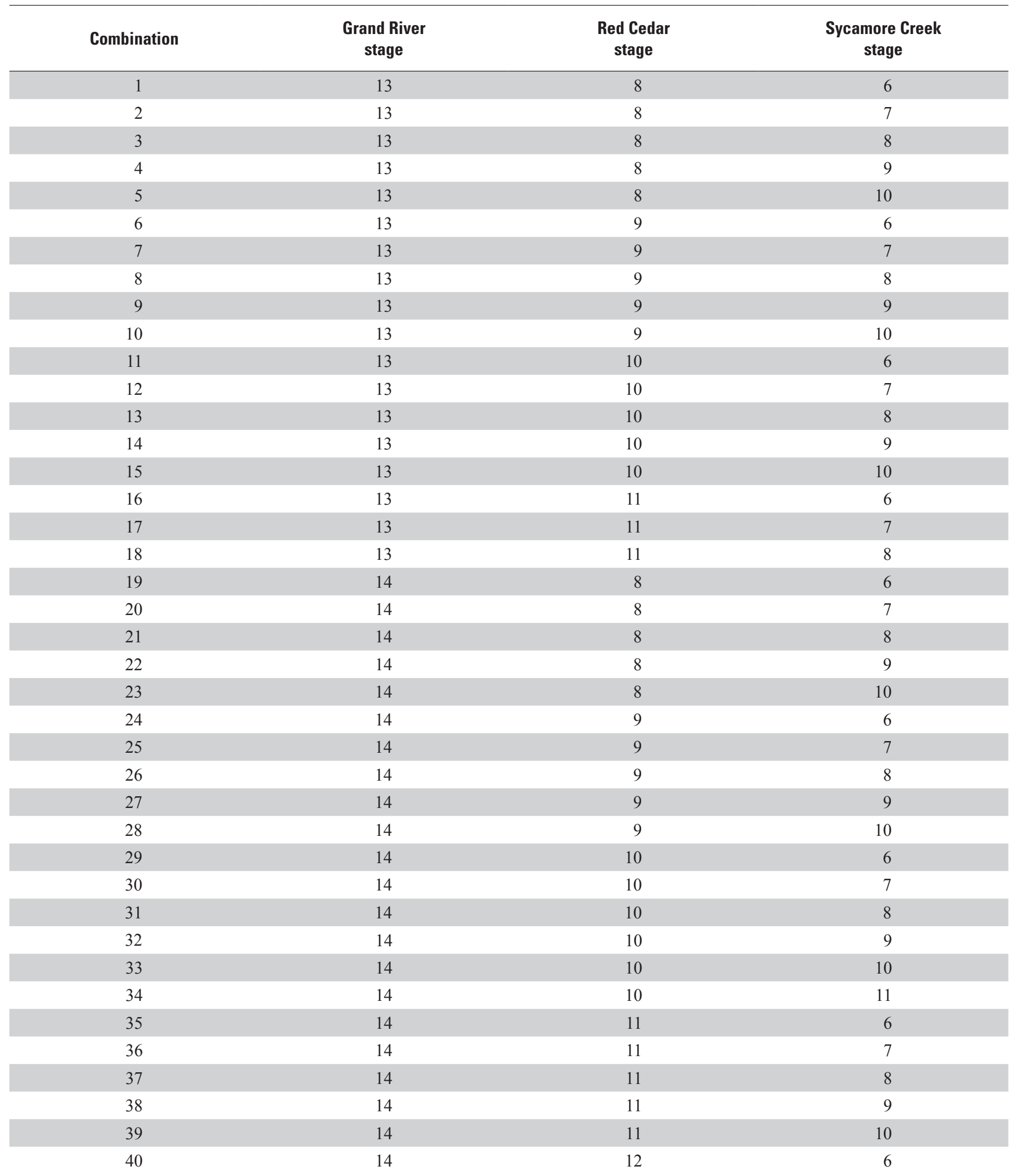


Appendix 1. Modeled stage combinations for Grand River, Red Cedar River, and Sycamore Creek.-Continued

[Combinations (total of 305) were generated by holding stage constant for two of the three streams and varying stage for the third by 1-foot increments for the range of stages selected for this study]

\begin{tabular}{|c|c|c|c|}
\hline Combination & $\begin{array}{l}\text { Grand River } \\
\text { stage }\end{array}$ & $\begin{array}{l}\text { Red Cedar } \\
\text { stage }\end{array}$ & $\begin{array}{c}\text { Sycamore Creek } \\
\text { stage }\end{array}$ \\
\hline 41 & 14 & 12 & 7 \\
\hline 42 & 14 & 12 & 8 \\
\hline 43 & 15 & 8 & 6 \\
\hline 44 & 15 & 8 & 7 \\
\hline 45 & 15 & 8 & 8 \\
\hline 46 & 15 & 8 & 9 \\
\hline 47 & 15 & 8 & 10 \\
\hline 48 & 15 & 9 & 6 \\
\hline 49 & 15 & 9 & 7 \\
\hline 50 & 15 & 9 & 8 \\
\hline 51 & 15 & 9 & 9 \\
\hline 52 & 15 & 9 & 10 \\
\hline 53 & 15 & 10 & 6 \\
\hline 54 & 15 & 10 & 7 \\
\hline 55 & 15 & 10 & 8 \\
\hline 56 & 15 & 10 & 9 \\
\hline 57 & 15 & 10 & 10 \\
\hline 58 & 15 & 10 & 11 \\
\hline 59 & 15 & 11 & 6 \\
\hline 60 & 15 & 11 & 7 \\
\hline 61 & 15 & 11 & 8 \\
\hline 62 & 15 & 11 & 9 \\
\hline 63 & 15 & 11 & 10 \\
\hline 64 & 15 & 11 & 11 \\
\hline 65 & 15 & 12 & 6 \\
\hline 66 & 15 & 12 & 7 \\
\hline 67 & 15 & 12 & 8 \\
\hline 68 & 15 & 12 & 9 \\
\hline 69 & 15 & 12 & 10 \\
\hline 70 & 15 & 13 & 6 \\
\hline 71 & 15 & 13 & 7 \\
\hline 72 & 15 & 13 & 8 \\
\hline 73 & 16 & 8 & 6 \\
\hline 74 & 16 & 8 & 7 \\
\hline 75 & 16 & 8 & 8 \\
\hline 76 & 16 & 8 & 9 \\
\hline 77 & 16 & 8 & 10 \\
\hline 78 & 16 & 9 & 6 \\
\hline 79 & 16 & 9 & 7 \\
\hline 80 & 16 & 9 & 8 \\
\hline 81 & 16 & 9 & 9 \\
\hline
\end{tabular}


Appendix 1. Modeled stage combinations for Grand River, Red Cedar River, and Sycamore Creek.-Continued

[Combinations (total of 305) were generated by holding stage constant for two of the three streams and varying stage for the third by 1-foot increments for the range of stages selected for this study]

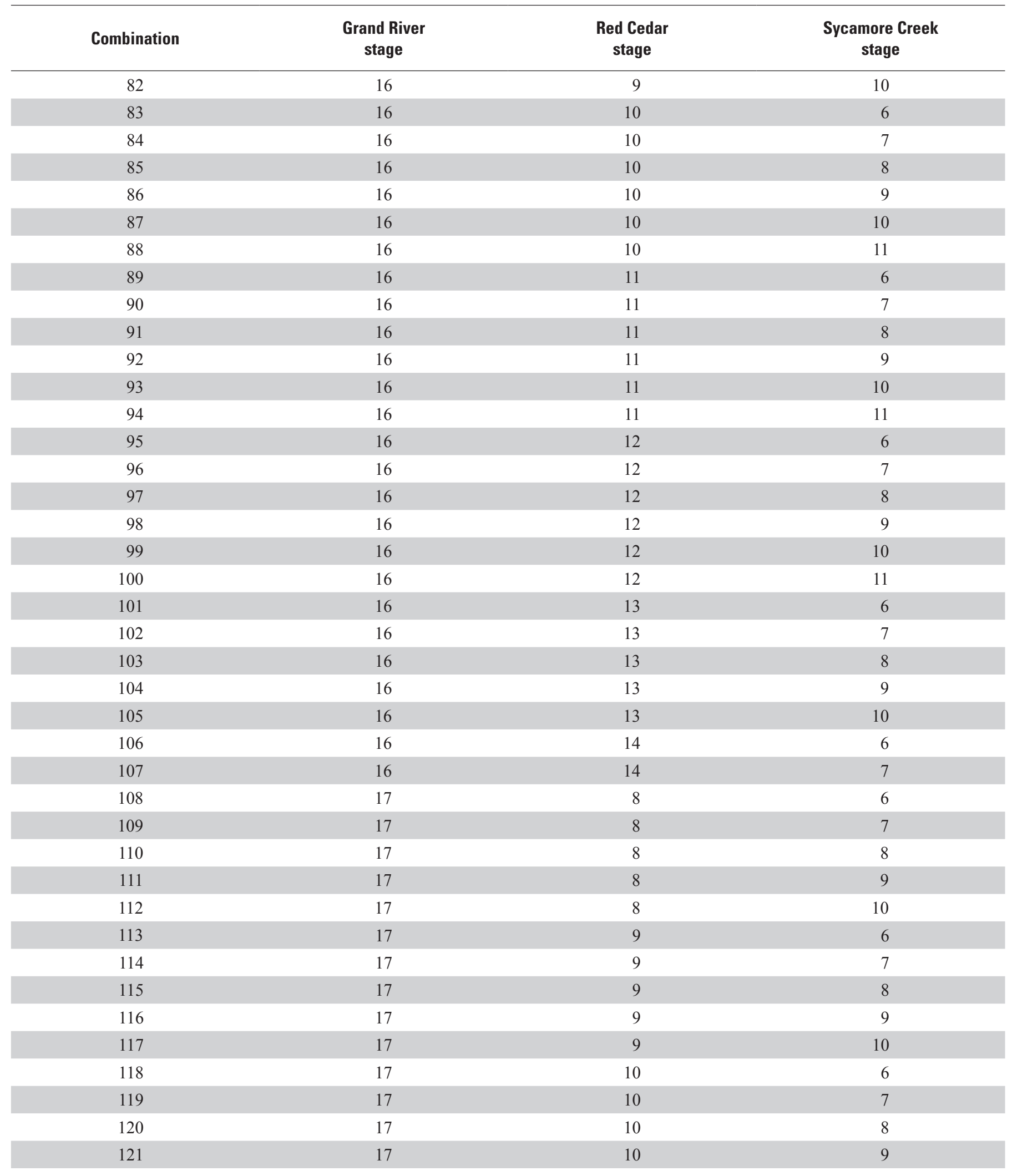


Appendix 1. Modeled stage combinations for Grand River, Red Cedar River, and Sycamore Creek.-Continued

[Combinations (total of 305) were generated by holding stage constant for two of the three streams and varying stage for the third by 1 -foot increments for the range of stages selected for this study]

\begin{tabular}{|c|c|c|c|}
\hline Combination & $\begin{array}{l}\text { Grand River } \\
\text { stage }\end{array}$ & $\begin{array}{l}\text { Red Cedar } \\
\text { stage }\end{array}$ & $\begin{array}{c}\text { Sycamore Creek } \\
\text { stage }\end{array}$ \\
\hline 122 & 17 & 10 & 10 \\
\hline 123 & 17 & 10 & 11 \\
\hline 124 & 17 & 11 & 6 \\
\hline 125 & 17 & 11 & 7 \\
\hline 126 & 17 & 11 & 8 \\
\hline 127 & 17 & 11 & 9 \\
\hline 128 & 17 & 11 & 10 \\
\hline 129 & 17 & 11 & 11 \\
\hline 130 & 17 & 12 & 6 \\
\hline 131 & 17 & 12 & 7 \\
\hline 132 & 17 & 12 & 8 \\
\hline 133 & 17 & 12 & 9 \\
\hline 134 & 17 & 12 & 10 \\
\hline 135 & 17 & 12 & 11 \\
\hline 136 & 17 & 13 & 6 \\
\hline 137 & 17 & 13 & 7 \\
\hline 138 & 17 & 13 & 8 \\
\hline 139 & 17 & 13 & 9 \\
\hline 140 & 17 & 13 & 10 \\
\hline 141 & 17 & 13 & 11 \\
\hline 142 & 17 & 14 & 6 \\
\hline 143 & 17 & 14 & 7 \\
\hline 144 & 17 & 14 & 8 \\
\hline 145 & 17 & 14 & 9 \\
\hline 146 & 18 & 8 & 6 \\
\hline 147 & 18 & 8 & 7 \\
\hline 148 & 18 & 8 & 8 \\
\hline 149 & 18 & 8 & 9 \\
\hline 150 & 18 & 8 & 10 \\
\hline 151 & 18 & 9 & 6 \\
\hline 152 & 18 & 9 & 7 \\
\hline 153 & 18 & 9 & 8 \\
\hline 154 & 18 & 9 & 9 \\
\hline 155 & 18 & 9 & 10 \\
\hline 156 & 18 & 10 & 6 \\
\hline 157 & 18 & 10 & 7 \\
\hline 158 & 18 & 10 & 8 \\
\hline 159 & 18 & 10 & 9 \\
\hline 160 & 18 & 10 & 10 \\
\hline 161 & 18 & 10 & 11 \\
\hline
\end{tabular}


Appendix 1. Modeled stage combinations for Grand River, Red Cedar River, and Sycamore Creek.-Continued

[Combinations (total of 305) were generated by holding stage constant for two of the three streams and varying stage for the third by 1-foot increments for the range of stages selected for this study]

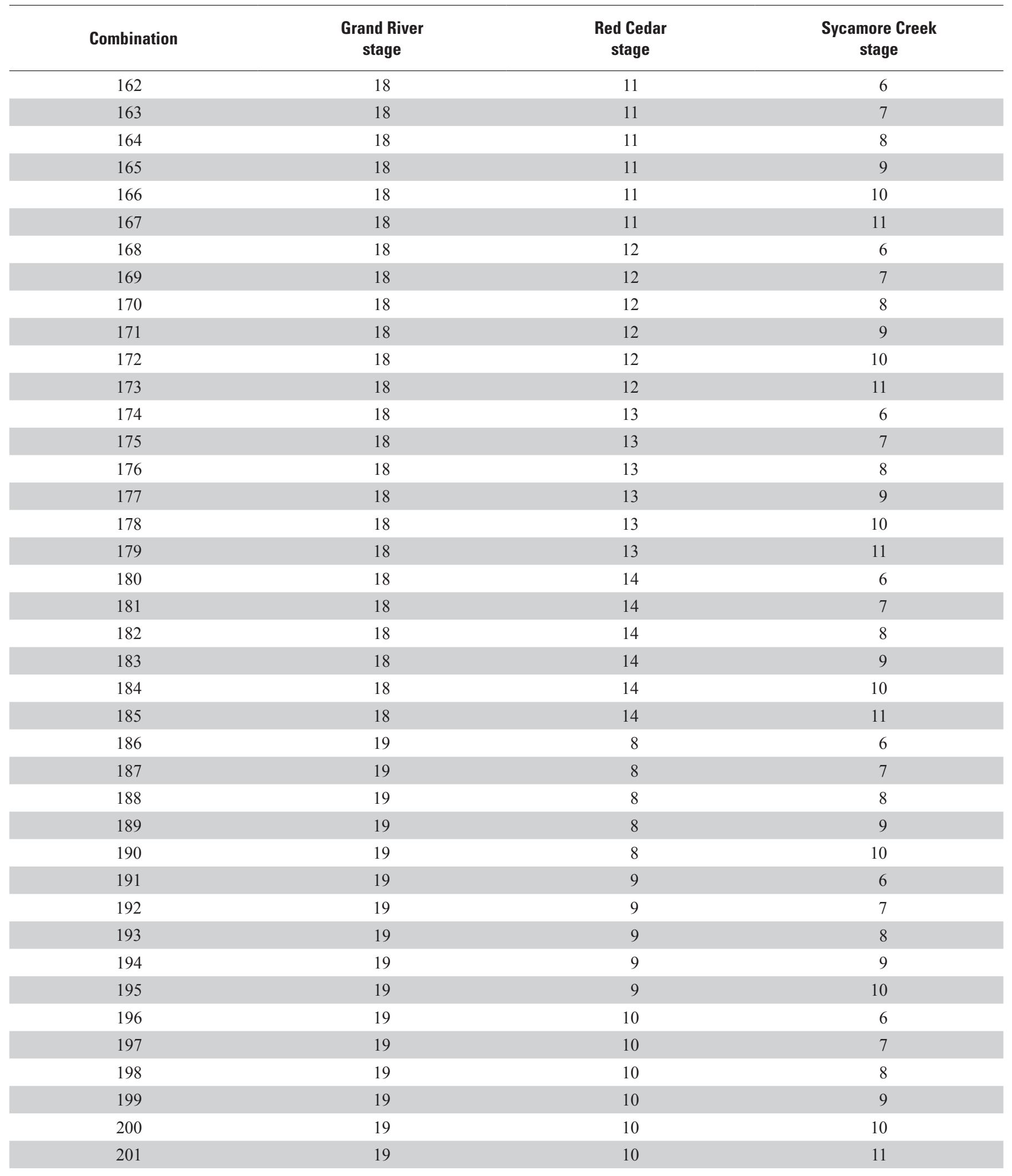


Appendix 1. Modeled stage combinations for Grand River, Red Cedar River, and Sycamore Creek.-Continued

[Combinations (total of 305) were generated by holding stage constant for two of the three streams and varying stage for the third by 1 -foot increments for the range of stages selected for this study]

\begin{tabular}{|c|c|c|c|}
\hline Combination & $\begin{array}{l}\text { Grand River } \\
\text { stage }\end{array}$ & $\begin{array}{l}\text { Red Cedar } \\
\text { stage }\end{array}$ & $\begin{array}{c}\text { Sycamore Creek } \\
\text { stage }\end{array}$ \\
\hline 202 & 19 & 11 & 6 \\
\hline 203 & 19 & 11 & 7 \\
\hline 204 & 19 & 11 & 8 \\
\hline 205 & 19 & 11 & 9 \\
\hline 206 & 19 & 11 & 10 \\
\hline 207 & 19 & 11 & 11 \\
\hline 208 & 19 & 12 & 6 \\
\hline 209 & 19 & 12 & 7 \\
\hline 210 & 19 & 12 & 8 \\
\hline 211 & 19 & 12 & 9 \\
\hline 212 & 19 & 12 & 10 \\
\hline 213 & 19 & 12 & 11 \\
\hline 214 & 19 & 13 & 6 \\
\hline 215 & 19 & 13 & 7 \\
\hline 216 & 19 & 13 & 8 \\
\hline 217 & 19 & 13 & 9 \\
\hline 218 & 19 & 13 & 10 \\
\hline 219 & 19 & 13 & 11 \\
\hline 220 & 19 & 14 & 6 \\
\hline 221 & 19 & 14 & 7 \\
\hline 222 & 19 & 14 & 8 \\
\hline 223 & 19 & 14 & 9 \\
\hline 224 & 19 & 14 & 10 \\
\hline 225 & 19 & 14 & 11 \\
\hline 226 & 20 & 8 & 6 \\
\hline 227 & 20 & 8 & 7 \\
\hline 228 & 20 & 8 & 8 \\
\hline 229 & 20 & 8 & 9 \\
\hline 230 & 20 & 8 & 10 \\
\hline 231 & 20 & 9 & 6 \\
\hline 232 & 20 & 9 & 7 \\
\hline 233 & 20 & 9 & 8 \\
\hline 234 & 20 & 9 & 9 \\
\hline 235 & 20 & 9 & 10 \\
\hline 236 & 20 & 10 & 6 \\
\hline 237 & 20 & 10 & 7 \\
\hline 238 & 20 & 10 & 8 \\
\hline 239 & 20 & 10 & 9 \\
\hline 240 & 20 & 10 & 10 \\
\hline 241 & 20 & 10 & 11 \\
\hline
\end{tabular}


Appendix 1. Modeled stage combinations for Grand River, Red Cedar River, and Sycamore Creek.-Continued

[Combinations (total of 305) were generated by holding stage constant for two of the three streams and varying stage for the third by 1-foot increments for the range of stages selected for this study]

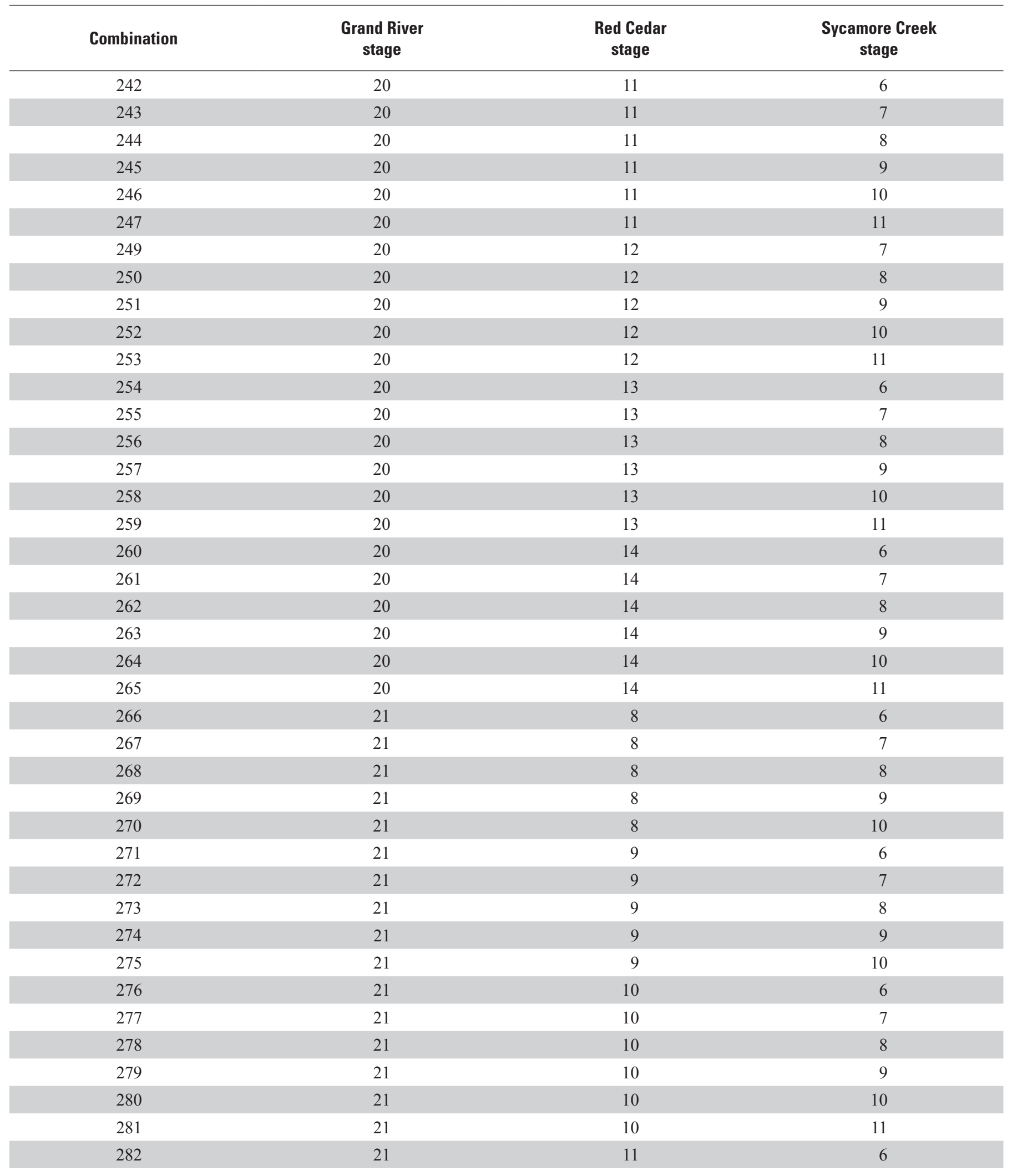


Appendix 1. Modeled stage combinations for Grand River, Red Cedar River, and Sycamore Creek.—Continued

[Combinations (total of 305) were generated by holding stage constant for two of the three streams and varying stage for the third by 1 -foot increments for the range of stages selected for this study]

\begin{tabular}{cccc}
\hline Combination & $\begin{array}{c}\text { Grand River } \\
\text { stage }\end{array}$ & $\begin{array}{c}\text { Red Cedar } \\
\text { stage }\end{array}$ & $\begin{array}{c}\text { Sycamore Creek } \\
\text { stage }\end{array}$ \\
\hline 283 & 21 & 11 & 7 \\
\hline 284 & 21 & 11 & 8 \\
\hline 285 & 21 & 11 & 9 \\
\hline 286 & 21 & 11 & 10 \\
\hline 287 & 21 & 11 & 11 \\
\hline 288 & 21 & 12 & 6 \\
\hline 289 & 21 & 12 & 7 \\
290 & 21 & 12 & 8 \\
\hline 291 & 21 & 12 & 9 \\
\hline 292 & 21 & 12 & 10 \\
\hline 293 & 21 & 12 & 11 \\
\hline 294 & 21 & 13 & 6 \\
\hline 295 & 21 & 13 & 7 \\
296 & 21 & 13 & 8 \\
\hline 297 & 21 & 13 & 9 \\
298 & 21 & 13 & 10 \\
299 & 21 & 13 & 11 \\
\hline 300 & 21 & 14 & 6 \\
301 & 21 & 14 & 7 \\
\hline 302 & 21 & 14 & 8 \\
\hline 304 & 21 & 14 & 11 \\
\hline 305 & 21 & 14 & 9 \\
\hline
\end{tabular}



Publication services provided by the U.S. Geological Survey Science Publishing Network

Columbus Publishing Service Center

West Trenton Publishing Service Center

For more information concerning the research in this report contact the

Director, Ohio Water Science Center

6480 Doubletree Ave

Columbus, $\mathrm{OH}$ 43229-1111

http://oh.water.usgs.gov/ 


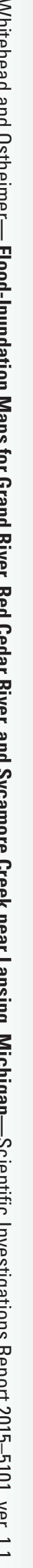

